\section{Standards needed for gene-editing errors}

It is important to develop consensus guidelines for defining off-target mutations in DNA, which could occur as an unintended side-effect of genome editing (see Nature 522, 20-24; 2015). I encourage the community to contribute to these discussions (see go.nature.com/ zncbil).

Such uniform standards would help researchers, peer-reviewers, journal editors and regulators to best identify such mutations.

For therapeutic applications, unwanted mutations need to be defined by the most highly sensitive, unbiased genomewide methods - given that even low-frequency events in large populations of cells could have clinical consequences. Such a comprehensive definition might not be necessary for research projects because appropriate control experiments would exclude the potentially confounding effects of off-target actions.

For now, direct comparison of state-of-the-art technologies can start to define best practices. Refinement will follow as detection and editing methodologies advance.

J. Keith Joung Massachusetts General Hospital, Charlestown, Massachusetts, USA.

jjoung@partners.org Competing financial interests declared: see go.nature.com/dellef

\section{Fieldwork grants would up diversity}

You flag a social media debate on the practice of using volunteers for field research in biology (Nature 522, 131; 2015). In our view, the solution is not to eliminate these positions, but to make them more worthwhile and accessible to students who need such experience - for example, to add weight to their graduate school applications or to test their commitment to field-research careers.

Unpaid internships are seen as elitist in that they can be taken up only by people who can afford to support themselves. However, banning volunteers would markedly reduce the availability of field positions.

A better strategy would be for funding agencies such as the US National Science Foundation to allocate research fellowships to trainees from underrepresented socio-economic groups. This support would cover field expenses and provide a reasonable stipend. Such a system would also allow researchers to identify and recruit promising candidates and would facilitate valuable field experience for a more diverse set of applicants. Joan B. Silk Arizona State University, Tempe, Arizona, USA. joansilk@gmail.com ${ }^{\star}$ On behalf of 4 correspondents (see go.nature.com/3e7y $7 v$ for full list).

\section{Bolivia set to violate its protected areas}

The Bolivian government has issued a decree allowing hydrocarbon exploration inside the country's protected areas. They have also given the green light for the construction of a controversial highway across the Isiboro Secure National Park and Indigenous Territory (TIPNIS). As scientists working in South American forests, we are concerned that these political developments override the country's international commitments and undermine the conservation of its unique biological and cultural diversity.

Several national and international groups, including activists and scientists, have voiced their opposition. The conflict has now reached a crucial stage, with President Evo Morales, once known as Bolivia's foremost defender of Pachamama ('Andean Earth Mother'), threatening to expel any non-governmental organization or foundation that attempts to obstruct the exploitation of the country's natural resources.

We call on the country's recently re-elected government to reconsider its environmental policies and to revisit its conservation pledges. We also urge the president to respect and support the legitimate and essential work of Bolivian civil organizations and their international partners in defending Pachamama.

Álvaro Fernández-Llamazares Autonomous University of Barcelona, Spain; and University of Helsinki, Finland.

Ricardo Rocha University of Lisbon, Portugal; and University of Helsinki, Finland.

Alvaro.FernandezLlamazares@ uab.es

\section{China should come clean on emissions}

Uncertainties surrounding

China's data on carbon

emissions threaten to

undermine its pledge for a 2030 emissions peak (see Z. Liu et al. Nature 522, 279-281; 2015) and to confuse global strategies for preventing catastrophic climate change. The stakes are high: even small upward tweaks in China's coal consumption could generate more carbon dioxide than many countries emit in an entire year.

Emissions data are a sensitive issue in China, with official government statistical reports focusing more on energy production and consumption than on the country's binding carbon goals. China's carbon data are available for only 1994 and 2005 (through the UN Framework Convention on Climate Change) and are now outdated. Despite high-level policies in 2007 mandating a national greenhouse-gas statistical monitoring system, this has yet to materialize.

China says it reduced its $\mathrm{CO}_{2}$ emissions per unit gross domestic product by $28.5 \%$ from 2005 to 2013, but our investigations suggest that more data are needed to confirm this. Clearer justification and methodological explanation is also needed for the frequent revisions of energy statistics by the National Bureau of Statistics of China in Beijing.

As Zhu Liu and colleagues point out, reliable monitoring systems and transparent reporting mechanisms are essential for China's internal emissions management.

Angel Hsu, Kaiyang Xu, Andrew Moffat Yale School of Forestry and Environmental Studies, New Haven, Connecticut, USA. angel.hsu@yale.edu

\section{TNF trailblazers five centuries apart}

This year marks the 40th anniversary of a landmark paper describing the discovery of tumour necrosis factor (TNF), a pivotal cell-signalling protein in inflammatory disease known as a cytokine (E. A. Carswell et al. Proc. Natl Acad. Sci. USA 72, 3666-3670; 1975). More than 122,000 publications on TNF followed - including reports that led to an important drug for treating arthritis, etanercept.

TNF's eponymous anti-cancer effects were unwittingly exploited by William Coley and colleagues as long ago as the end of the nineteenth century, after the likely induction of TNF by a mix of bacterial toxins (see B. Wiemann and C. O. Starnes Pharmacol. Ther. 64, 529-564; 1994).

And many centuries earlier, in 1322, a Parisian midwife called Jacoba Felicie successfully burned the tissue around tumours to make them regress. We now know that burns cause inflammation, which activates TNF. As a woman, she was not permitted to qualify as a doctor, so she was put on trial for practising medicine and banished from Paris. Claude Libert Inflammation Research Center, VIB/University of Ghent, Ghent, Belgium. claude.libert@irc.vib-ugent.be 